behavior. Z. Tierpsychol. 27: 405-480. H a milto n W. J., Jr., 1933: The weasels of New York. Their natural history and economic status. The Amer. Midl. Nat., 14. 284-337. H idt G. A. Petersen M. K. \& Kirkland G. L., Jr., 1968: Matting behavior and development of least weasels (Mustela nivalis) in captivity. J. Mamm., 49: 413-419. H e i d t G. A., 1972: Anatomical and behavioral aspects of killing and feeding by the least weasel, Mustela nivalis. Arkansas Acad. Sci. Proc., 26: 53-54. In v e r s e n J. A., 1972: Basal energy metabolism of Mustelids. J. Comp. Physiol., 81: 341-344. Le opold A., 1937: Killing technique of the weasel. J. Mamm., 18: 8 -99. L l e well y n L. M, 1942: Notes o. the Alleghenian least weasel in Virginia. J. Mamm., 23: 439-441. Lor enz \& Ley hausen P., 1973: Motivation of human and animal behavior. Von Nostrand Reinhold, New York. N a g e l J. W., 1972: Observations of the second record of the least weasel in Tennessee. Amer. Midl. Nat., 87: 553, Progulske D. R., 1969: Observations of a penned, wild-captured Black-footed ferret. J. Mamm., 50: 619-621. Q u ick H. F., 1ธ51: Notes on the ecology of weasels in Gunnison county, Collorado. J. Mammal., 32: 280-290. R u b in a M. A., 1960: Nekotorye čerty ekologii laski (Mustela nivalis L.) po nabljudenijam v Moskovskoj oblasti. Biull. Mosk. Obš. Isp. Prir., Otd. Biol., 65: 27-63. Scholander P. F., Hock R., W a l ters V. \& Irving L., 1950: Adaptation to cold in arctic and tropical mammals and birds in relation to body temperature, insulation and basal metabolic rate. Biol. Bull., 99: 259-271. V a u g h a T. A., 1972: Mammal. W. B. Saunders Co.: 1-415. Toronto.

Accepted, June 28., 1977.

\title{
Feeding Behavior, Coprophagy and Passage of Foodstuffs in a Captive
} Least Shrew

Behawior pokarmowy, koprofagia i tempo przechodzenia treści pokarmowej u Sorex minutissimus

\section{UOLEVI SKAREN}

Skarén U., 1978: Feeding behavior, coprophagy and passage of foodstuffs in a captive least shrev. Acta theriol., 23, 6: 131-140 [With 2 Tables \& 2 Figsl.

Observations of a single old adult male of the least shrew Sorex minutissimus $\mathrm{Z}$ i m m e r ma $\mathrm{n}, 1780$ in captivity show that it ate willingly Araneae, Opiliones, Chilopoda, Orthoptera, Lepidoptera, Hymenoptera larvae, Diptera adults and small Coleoptera adults. The animal did not eat slugs, snails or lumbricids even though hungry. The first arthropod remnants appeared in feces on an average twenty minutes after eating started; spiders passed most quickly (12 min.), centipedes slowest (53 min.) throughout the digestive tract. The bulk of the arthropod remnants seemed to have passed after an hour and as a rule they were no longer found after 1.5-2 hours. Coprophagy was evident at times. The shrew ate about twice its own weight $(2.5 \mathrm{~g})$ per day. It seldom drank water. Hearing seemed to be important in hunting. The satisfied animal immobilized larvae and crickets, which lived even 30 hours afterwards. The shrew used these stores and sometimes moved them to new places.

[SF-74300 Sonkajärvi, Finland]

\section{INTRODUCTION}

Sympatric living of many Sorex species has stimulated the investigation of possible differences in their diet ( $\mathrm{Str}$ og a nov, 1957; Ohotina, 1974; Pernetta, 1976 and others). The natural diet of Sorex minutissimus is difficult to study, because as a rule this species 
can only be caught in pitfall traps (S trog a nov, 1957; Skarén, 1972), so that usually the alimentary canal is empty or only includes the bait material. Therefore the stomach analyses are very scarce ( $\mathrm{J} \mathrm{u} \mathrm{di} \mathrm{n}, 1971$ ). Moreover, the results have been somewhat contradictory while the behavior of these very small shrews is nearly unknown (Skarén \& Kaikusalo, 1966; Kaikusalo, 1967; Ohotina, 1974). Thus the purpose of this report is to present results of observations of the diet, the rate of passage of the foodstuffs and the behaviour made on the single adult male of Sorex minutissimus kept in captivity.

\section{MATERIAL AND METHODS}

The animal used in these tests was an old overwintered male $(2.5 \mathrm{~g})$ in summer fur. It was caught 25.VI.76 in Kuhmo, Eastern Finland, and investigated in July 1976. As a rule the shrew was kept in a glass cage $(35 \times 55 \times 40 \mathrm{~cm})$ at $+20^{\circ} \mathrm{C}$. Dry moss and two pieces of board were always in the cage likewise fish and water. Besides this some $(20-30)$ cocoons of Formica rufa were put in the cage in the morning and in the evening; the shrew ate them soon. The ford choice tests were done on a $8 \times 12 \mathrm{~cm}$ lid of a plastic box before a new portion of ant cocoons was given. Some busy arthropods were first immobillizated by pressing them a little so that they had not time to escape before the shrew came.

In determining the speed of passage of the food the animal was kept in a small $(40 \times 20 \times 30 \mathrm{~cm})$ plastic cage furnished with a pair of board and a little wood-wool as a nest. When the shrew had only got fish muscles about two hours, i.e. when there were no other remnants in the feces, it got some small animals. After that every excrement was immediately investigated under a microscope $(45 \times$ and $100 \times)$.

\section{RESULTS}

\subsection{Food choice}

Most evertebrates given to the shrew (Table 1) were eaten, but some were rejected. Lumbricids $(20-80 \mathrm{~mm}, \varnothing 2-4 \mathrm{~mm})$ were given four times, but the shrew only once bit at one of them, dragged a little, rubbed its nose and sniffed at the wriggling animal.

Some beetles, like Geotrupes and Oeceoptoma, apparently were too large $(15-16 \mathrm{~mm})$ and hard-armoured for the little shrew. Some others (Cantharis sp.) were soft and small $(6-12 \mathrm{~mm})$, but not eaten because of chemical defence: the shrew sniffed at them and then began to rub its nose at a piece of board. Though hungry the test animal did not eat ladybirds presumably of the same reason. Buzzing was the effective way of defence in Bombus lapidarium: when a large $(23 \mathrm{~mm})$ adult was put in the cage the test animal made several attempts to approach the bumble-bee walking slowly on the board. It dashed forward, nagged the air near the insect like a diminutive dog, ran away and finally bit at one wing so that the bumble-bee began to buzz: now the shrew fled and did no longer attack the insect. - The foam protects Philaenus spumarius-nymps well. The shrew did not try to dig out the nymph nor did it eat it when the foam was removed. 
The following findings may be kept in mind when analysing the stomachs of Sorex minutissimus. Smaller Arachnoidea were eaten wholly, but pieces of legs were left of larger species. Lithobius forficatus and the following insects were eaten wholly: hairless Lepidoptera larvae, Symphyta-larvae and small beetles (Curculionidae, Staphylinidae). Elytra and pieces of legs were left of some larger beetles, e.g. Chrysomelidae and Elateridae. The wings and pieces of legs of adult flies and Hymenoptera were not eaten. Living ants were nagged with care, killed, immobilized or eaten nearly wholly: only parts of the head were left.

Table 1

Food choice of Sorex minutissiumus.

$\mathrm{A}=$ not eaten or eaten hesitatingly, $\mathrm{B}=$ eaten eagerly.

\begin{tabular}{|c|c|c|c|c|c|}
\hline Item & A & B & Item & A & B \\
\hline $\begin{array}{l}\text { Oligochaeta, Lumbricidae } \\
\text { Chilopoda } \\
\text { Lithobius forficatus } \\
\text { Insecta } \\
\text { Orthoptera: Acheta } \\
\text { domestica } \\
\text { Heteroptera } \\
\text { Capsus ater } \\
\text { Nabis sp. } \\
\text { Homoptera } \\
\text { Philaenus spumarius } \\
\text { Odonata } \\
\text { Agriotes sp. } \\
\text { Lepidoptera } \\
\text { Coleoptera } \\
\text { Geotrupes sp. } \\
\text { Oeceoptoma thoracicum } \\
\text { Cantharis sp. } \\
\text { Thea 22-punctata } \\
\text { Coccinella 7.-punctata } \\
\text { Propylaea 14-punctata } \\
\text { Evodinus interrogationis } \\
\text { Strangalia melanura } \\
\text { Curculionidae } \\
\text { Chrysomelidae } \\
\text { Elateridae }\end{array}$ & $\begin{array}{l}+ \\
+ \\
+ \\
+ \\
+ \\
+ \\
+ \\
+ \\
+\end{array}$ & $\begin{array}{l}+ \\
+ \\
+\end{array}$ & $\begin{array}{l}\text { Rhagium inquisitor. } \\
\text { larvae } \\
\text { Staphylinidae } \\
\text { Carabidae, larvae } \\
\text { Hymenoptera } \\
\text { Bombus lapidarius } \\
\text { Apis mellifica } \\
\text { Formica rufa } \\
\text { Vespoidea, larvae } \\
\text { Symphyta, larvae } \\
\text { Ichneumonoidea } \\
\text { Diptera } \\
\text { Brachycera, adults } \\
\text { Brachycera, larvae } \\
\text { Nematocera } \\
\text { Arachnoidea } \\
\text { Araneida } \\
\text { Opiliones } \\
\text { Gastropoda } \\
\text { Limnea stagnalis } \\
\text { Pisces } \\
\text { Perca fluviatilis } \\
\text { Mammalia } \\
\text { Clethrionomys glareolus } \\
\text { Bos taurus, heart }\end{array}$ & $\begin{array}{l}+ \\
+\end{array}$ & $\begin{array}{l}+ \\
+ \\
+ \\
+ \\
+ \\
+ \\
+ \\
+ \\
+\end{array}$ \\
\hline
\end{tabular}

3.2. Rate of passage of food

Eight tests were made to calculate the rate of passage of different prey animals throughout the alimentary canal. There seemed to be considerable variation according to the item (Table 2). The fastest passage was that of the spiders (first remnants within 12 minutes) or that of the beetles $(100 \%$ passed within one hour). The centipede seemed to delay longest inside the shrew. Also the scales of adult butterflies appeared relatively slowly the last beeing found as late as 4.5 hours after the meal. Likewise plant cells originally eaten by the butterfly 
larva delayed half an hour longer inside the shrew than the proper larva remnants.

It seemed that as a rule bulk of the foodstuffs had passed during the first hour. Thus the excrement began to turn lighter and only contained a few short pieces of legs of the spiders 50 minutes after the meal.

\subsection{Quantity of Food}

One test was made to examine the amount of food needed. Only water was left in the morning in the cage, but the shrew did not drink during the following fast of 40 minutes. There were no signs of hypothermia during this period (cf. G ę b c z y ński, 1971; V o g e l, 1974). Thereafter the shrew got arthropods ad libitum during 12 hours, eating 134 cocoons of ants (Formica rufa), two Rhagium inquisitor larvae, a Cantharis beetle, Lithobius centipede, two staphylinid beetles, one Carabidae larva, parts of a Silphidae larva, a honeybee and a grasshop-

Table 2

Rate of passage of food throughout the alimentary canal, in minutes.

\begin{tabular}{lcccc}
\hline \multicolumn{1}{c}{ Item } & Size (mm) & $n$ & $\begin{array}{c}\text { First remnants } \\
\text { passed }\end{array}$ & $\begin{array}{c}100^{\%} \\
\text { passed }\end{array}$ \\
\hline $\begin{array}{l}\text { Spiders (Araneae) } \\
\text { Centipede (Lithobius }\end{array} \quad$ fortificatus) & 6 & 5 & 12 & 90 \\
$\begin{array}{l}\text { Adult beetles (Agriotes sp). } \\
\text { Adult ants (Formica rufa) }\end{array}$ & 16 & 1 & 53 & 195 \\
$\begin{array}{l}\text { Ant cocoons (Formica rufa) } \\
\text { Adult fly (Sarcophaga }\end{array} \quad$ carnaria) & 4 & 3 & 18 & - \\
$\begin{array}{l}\text { Adult butterfly (Clossiana } \\
\text { selene) }\end{array}$ & 12 & 13 & 20 & - \\
$\begin{array}{l}\text { Butterfly larva (Noctuae) } \\
\text { Mean } \pm \text { S. E. }\end{array}$ & 18 & 1 & 25 & $90^{1}$ \\
\hline
\end{tabular}

1 Observation interrupted.

${ }^{2} 150=$ last scales of the butterfly excreted.

$3117=$ last plant cells (originally eaten by the larva) appeared. $97=$ last proper larva remnants.

per. All these amounted to about the shrews own weight $2.5 \mathrm{~g}$. The animal however, ate $60 \%$ of its weight during the first five hours. It had been kept in the cage about three weeks and it moved only a little during these 12 hours. The temperature, $+20^{\circ} \mathrm{C}$, might have been near the thermal neutrality of this specimen in summerfur. Apparently the shrew needs more energy in nature, where it has to seek the prey. During 24 hours it must eat more than twice its own weight.

\subsection{Hunting and Immobilization}

It is difficult to say which is more important in finding the prey, hearing or sense of smell. At least the former must be significant. The 
ear lobes of the hunting shrew were a little raised so I think it pursued the prey mainly by sound orientation. A young $(13 \mathrm{~mm})$ Acheta domestica was put in the plastic cage; it passed by five centimeters the 1ish-eating shrew, which did not notice anything. Then the cricket walked around the shrew's nest; Sorex returned into the nest about one minute later and began to sleep apparently discovering no new odour. Now the cricket came, touched the sleeping shrew with antennae (the sleeper did not awake), walked away and began to warm itself in a corner with an electric bulb. At last the shrew happened to go to the same corner, noticed the cricked and immediately attacked it ouick as lightning. It caught the fleeing prey after a pair of false steps, killed by biting the thorax and ate wholly. Three other crickets of the same size were put in the cage half an hour later. Now the shrew killed one, ate it except one hind leg and part of the thorax. Then it trailed these remnants around the terrarium searching for a hiding-place. Finally it pushed the remnants between a board and the wall of the cage. Now it noticed another cricket, pursued it, happened to come to the store, bit furiously the piece of the cricket, noted the mistake, continued to hunt and finally immobilized this cricket by biting it at the thorax and stored close by the first. Also the last cricket was caught very soon and stored likewise. The immobilized crickets moved a little, but could not walk. I put them in loose, moist turf in a china cup; one of them lived for 30 hours moving a little when lightly pressed with a needle.

In another test the shrew ate four butterfly larvae and then immobilized the fifth by a bite on the neck and stored it like the crickets Having eaten only fish the shrew went half an hour later to the store seeking the larva, which I had taken. This larva lived at least 16 hours 40 minutes on my working table exposed to dry at $+20^{\circ} \mathrm{C}$.

The least shrew stored dead prey, too. Thus it hid the rear of a partly easten large Rhagium larva after turning and seeking a convenient narrow slit between the board and the cage wall. Then it got five similar larvae, bit them and stored like the first one. I looked at the larvae: only two of them moved, the others seemed to be dead. After resting six minutes the shrew went to the store, took one larva to the nest, tore it a little and carried back to the store. Then it grubbed the store as if to be confirmed that all was in order. Ten minutes later the animal brought again one larva from the store. It ate very little and pushed the rest under a board near the nest. 15 minutes later the shrew also took all the other larvae to this new place. When it had taken all of them, it still went to the old store as if to verify that it was empty.

Then the shrew got one hundred ant cocoons and a Lithobius centipede. Although there were large Rhagium larvae in the store, the animal behaved as if hungry: it killed and ate the centipede immediately. It also ate five cocoons and began to store the others in the nest, but after 5-6 trips (it took the cocoons one at a time) it seemed to get tired and the bulk of the cocoons remained in a pile $10 \mathrm{~cm}$ from the nest.

I saw only two unsuccesful immobilizations: a Symphyta larva and an 
adult Evodinus interrogationis beetle were able to escape from the store.

As a rule the least shrew seemed to catch small prey easily. It is true it had some difficulties with ants: when $7-8$ living Formica rufa adults were put in the cage some gripped at the shrew's tail, but it shook them off. Then it attacked the teasers, nagged them with care, but killed and immobilized easily.

It did not store the immobilized ants. A larger beetle (Corymbites, $18 \mathrm{~mm}$ ) seemed to be nearly too hard-scaled for the shrew, who killed it at once by biting at about the neck, but only with great efforts could eat the prey. It ate the head first, then it pinned the prey to the substrate with the forefeet and chewed off the elytra: this lasted seven minutes. Now it could consume the inner parts of the abdomen. After this trouble the animal drank a lot: $6-7$ gulps, when it usually took only one or two per hour: apparently it got enough water from the prey. The least shrew drank in a somewhat bird-like way, scooping water from the surface in a forward movement and raising the head

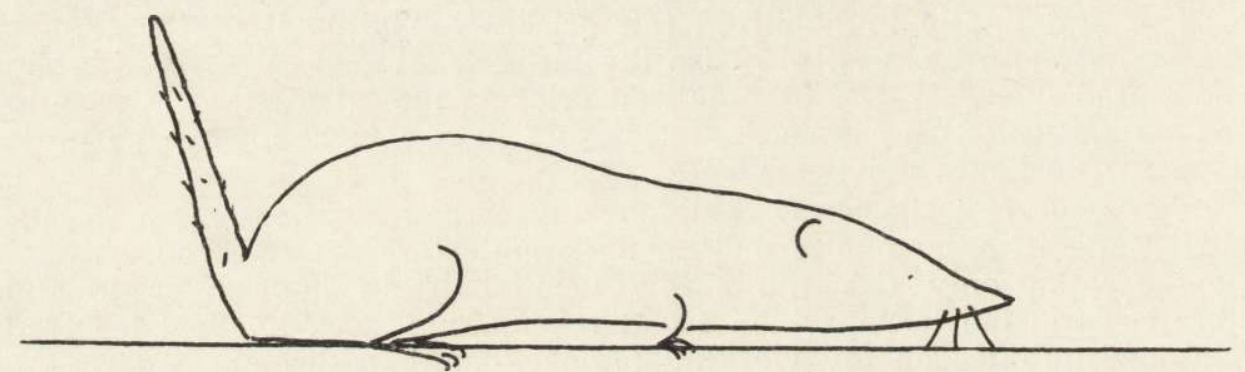

Fig. 1. After defecation the anus was cleaned by being dragged along the substrate.

to swallow. - I imagined that the shrew was satisfied after the substantial meal, but when it got a spider and a Symphyta larva it ate them immediately nearly wholly as though it had not seen food for a long time.

The small shrew seemed to be able to estimate the size of things put in the cage - and it was afraid of big ones. So it approached a Limnea stagnalis adult of its own size very carefully, nagged the shell with teeth and ran away fast. It was also suspicious when part of the combs of a Vespa nest was put in the cage. This thing was about twice as large as the shrew and contained living larvae in the cells. At first the shrew did not dare to come near the new object, although it clearly had observed it: directed the muzzle at it from a distance of about 15 centimetres with raised earlobes. Seemingly it used echosounding (cf. Gould et al., 1964); there was hardly no unpleasant smell, because the shrew later ate these larvae, taking them from the combs.

\subsection{Coprophagy and General Behavior}

The least shrew mostly went to a certain corner of the cage for defecation, turned 180 degrees, lifted the tail and squirted. Sometimes 
it turned a few rounds before it found the pleasant posture. But it could defecate even while walking, if the feces were not too soft. Very often, especially after loose excrement the animal dragged its anus along the board (Fig. 1) with the tail raised, apparantly this aided cleaning. After defacation the shrew usually went to the nest, curled its body and licked the anus; also this action was apparently cleaning, not coprophagy, which was seen twice after eating caterpillars and once when 1.5 hours had passed after a spider meal (the shrew had also eaten fish during this period).

Now and then the animal groomed with one of the hind feet, standing tilted with three feet. It was apparently most difficult to reach the mid-line of the back between the shoulders. Some fleas were attached to this safe place.

The shrew slept in a position, which may be common among the other shrews, too (cf. e.g. F on s, 1974). The tail was curled underneath the body and the nose near the tip of the tail (Fig. 2). The animal was seldom curled on the side. The sleeping least shrew trembled continuously.

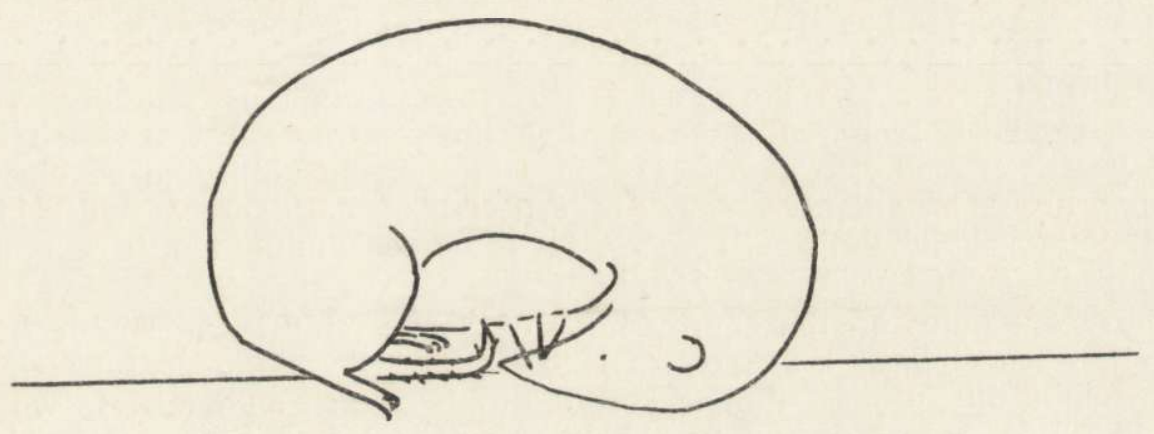

Fig. 2. The usual sleeping posture.

Only a few notes on the daily activity were made. Usually the shrew slept, defecated or ate at short (2-10 minutes) intervals during the whole day. After a more substantial meal of insects it rested as a rule for twenty minutes, sometimes almost one hour.

\section{DISCUSSION}

Storing the food may be a common habit among the shrews. It has been ascertained at least in Neomys fodiens, Sorex araneus, $S$. minutus and Blarina brevicauda (see e.g. C r ow c r of t, 1957; B u chalc z k \& Pucek, 1963; Wolk, 1976). According to Mas e r \& Hooven (1974) the nocturnal species Sorex pacificus stored food, but S. vagrans being active throughout the 24 -hour cycle did not. The nocturnal one thus gets food from the stores during the day, too. However, S. minutissimus 
also has the 24-hour cycle, but even it derives advantage from storing because the metabolism is high and the animal may come in a situation, where it does not fast enough find the required quantity of food. In this connexion one should also examine how long the storing behavior lasts if the shrew gets a great number of prey animals, and whether there occurs any needless killing as sometimes in carnivores (cf. S pannhof, 1952; Kru k, 1972).

The hunting way of shrews has been explained differently. Hearing is important according to Ansell (1964) in Crocidura bicolor like in Suncus etruscus (Fons, 1974), but M a s e $\&$ Hooven (1974) considered the sense of smell at least sometimes more important. C r owc r of t (1957) supposed that the food of Sorex araneus is found mainly by touch, whiskers. He thinks that once the prey has been found the sense of smell and tasting decide whether or not to eat it. $\mathrm{He}$ points that the common shrew is unable to find food until it almost falls over it. The least shrew, however, seemed at least to notice the larger new things in its cage from further away. Probably it then uses echolocation. Sorex minutissimus seems to belong to shrew species with poorer sense of smell. It detects motionless prey insect only upon contact or after coming very near it (cf. Buchler, 1976). But after being detected the prey animal has little chance to escape: now the shrew seems to orientate with the aid of hearing and possibly it uses echolocation also in hunting, even if Buchler (1976) regards this as unlikely. This question can only be solved by testing the hunting shrews, which has not yet been made. In every case the time-serving ability to echolocate seems to be of adaptive value to especially small shrews with high metabolic rate obviating the need for time-consuming tactile exploration of milieu (B u chle r, 1976).

Different notes on the energy need of Sorex minutissimus have been given. According to Blagosklonov (1957) it eats over four times its weight during 24 hours, according to $\mathrm{Kaikusalo}$ (1967) two or three times and according to Ohotin a (1974) five times. It is clear that e.g. the quality of the food and the temperature have an effect on these results. E.g. the common shrew eats more in winter, but even then only a few out of doors caged animals ate over their own weight (W ołk, 1969). Newly caught shrews eat more than those who have lived longer in the cage ( $\mathrm{Cr}$ ow c r of $t, 1957)$. The relative low values reached in this study may be due to the inactivity of the shrew in his warm and small cage.

The high rate of passage of foodstuffs seems to characterize the least shrew. It is difficult to make direct comparisons to earlier studies on Neomys fodiens (Kostelecka-Myrcha \& Myrcha, 1964) because of different methods and kind of food used. $100 \%$ of the stained larvae of Tenebrio molitor used by $\mathrm{Kos}$ telecka-M y $\mathrm{rcha}$ \& Myrcha (1964) passed throughout Neomys fodiens on an average in about four hours, which seems to be about two times slower than some other insect species in $S$. minutissimus.

Coprophagy has been observed in many mammals and e.g. the rats thus get B- and K-vitamins and some fatty acids ( $\mathrm{B}$ a rnes, 1962). But there are only a few notes on coprophagy in the shrews. However, 
$\mathrm{Spannh}$ of (1952) states that the shrews often seek and once more eat the poorly digested legs of insects and spiders in the feces. C r owc r of t (1957) and Loxton et al. (1975) have seen how the common shrew licks the anus until the rectum emerges "like a finger of a glove being turned inside out, as a tube to a centimetre long". Then the end of the rectum is licked for some minutes. The same is true of Crocidura cassiteridum (B o oth, 1956) and Suncus etruscus (F ons, 1974). But I never saw such in my least shrew even though the animal usually licked the anus in the nest after defecation. I regard this as the final state of cleaning; the animal had first dragged its anus on the substrate.

The last named behavior hardly means scent marking, although we know that even mammals having special scent glands may in addition communicate with urine and feces (E is e $\mathrm{n}$ berg \& K le i m a n, 1972). I have never seen the caged shrews to rub their side glands on anything, so that apparently their feromones simply evaporate continuously in the air. The caged Sorex pacificus of $\mathrm{M}$ a s e r \& H oove $\mathrm{n}$ (1974) used to lick the glass walls in the W.C.-corner of the cage. In the captive common shrews of Loxton et al. (1975) coprophagy occurred predominantly during the day when activity was lower and the authors supposed that this manner helped to get more nutrients from the food. The analyses of Geraets (1972) showed that the feces of Suncus etruscus contained $3400 \pm 100$ cal./g when the respective value was $6400 \pm 200$ in the eaten meal worms. Thus it is no wonder that especially the least shrew eats its feces in test situations, where it must mainly live on one-sided fish diet.

Acknowledgements: I am grateful to Dr. Kauri Mikkola (Department of Zoolosy, Helsinki University) for his help in identifying some prey animals and to Mrs. Ritva Antikainen who checked the English of my manuscript.

\section{REFERENCES}

Ansell W. F, H., 1964: Captivity behaviour and post-natal develooment of the shrew Crocidura bicolor. Proc. zool. Soc. Lond., 142: 123-127. B a $\mathrm{n}$ e s R. H., 1962: Nutritional implications of coprophagy. Nutr. Rev., 20: 289-291. (After Loxton et al., 1975). Blagosklonov K. N., 1957: On the feeding habits and character of daily activity of Sorex tsherskij Ognev. Zool. Ž , 36, 3: 465-467 [In Russian]. B o oth Y. S, 1956: Shrews (Crocidura cassiteridum) on the Scilly Isles, Proc. zool. Soc., Lond,, 126: 167-170 (After Crow croft, 1957). B u chalc zyk T, \& Pucek Z, 1963: Food storage of the European water shrew, Neomys fodiens (Pennant, 1771). Acta theriol., 7, 19: 376-379. B u chle r F. R., 1976: The use of echolocation by the wandering shrew (Sorex vagrans). Anim. Behav., 24: 858-873. Crow croft, P., 1957: The life of the shrew. Max Reinhardit: 1166. London. Eis en berg J. F. \& Klei man, D. G., 1872: Olfactory communication in mammals. [In: Johnston R. F. ed.: Ann. Rev. Ecol. Syst.] 3: 1-32. F o n s R., 1974: Le repertoire comportemental de la pachyure etrusque, Suncus etruscus. Terre et Vie, 1: 131-157. Ge b c zyńs k i M., 1971: Oxygen consumption in starving shrews. Acta theriol. 16: 288-292. G er a ets A., 1972: Aktivitätsmuster und Nahrungsbedarf bei Suncus etruscus. Bonn. zool. Beitr., 23, 3: 181-196. G ould E., Negus N. C. \& Novick A., 1964: Evidence for echolocation in shrews. J. exp. Zool., 156: 19-38. J u d i n B. S., 1971: Nasekomojadnye mlekopitajuščie Si. biri. Nauka: 1-172. Novosibirsk. Ka i kus a lo A., 1967: Havaintoja kääpiöpää stäisen (Sorex minutissimus Zimmermann) elintavoista. Luonnon Tutkija, 71: 8591. Kostelecka-M y r ha A. \& M r cha A., 1964: Rate of passage of foodstuffs through the alimentary tract of Neomys fodiens (P e n n a t, 1771) under 
laboratory conditions. Acta theriol., 9: 371-373. Kru u k H., 1972: Surplus killing by carnivores. J. Zool., Lond. 166: 233-244, Loxton R. G., R a ffaelli D. \& B e g on A., 1975: Coprophagy and the diurnal cycle of the common shrew, Sorex araneus. J. zool., Lond., 177: 449-453. M a s e r C. \& Hooven E. F., 1974: Notes on the behavior and food habits of captive pacific shrews, Sorex pacificus pacificus. Northwest Sci., 48, 2: 81-95. O hot in a M. V., 1974: Morfo-ekologičeskie osobennosti različnych vidov burozubok (Sorex Insectivora), obuslovlivajuščie vozmożnost' ih sovmestnogo suščestvovanija. [In: Ohotina M. V. ed. »Fauna i ekologija nazemnyh pozvonočnyh juga dal'nego vostoka SSSR «]. 42-57. Akad. Nauk. SSR. Vladivostok. Pernetta J. C., 1976: Diets of the shrews Sorex araneus L. and Sorex minutus L. in Wytham grassland. J. Anim. Ecol. 45: 899912. Sk a rén U. 1972: Fluctuations in small mammal populations in mossy forests of Kuhmo, eastern Finland, during eleven years. Ann. Zool. Fennici 9: 147 -151. Skarén U. \& K a ikusa lo A., 1966: Suomen pikkunisäkkäät. Otava: 1-227. Helsinki. Spa nnh of L., 1952: Spitzmäuse. Die Neue Brehm-Bücherei: 1-43. Leipzig. Strog a nov S., 1957: Zveri Sibiri. Nasekomojadnye. Izd. Akad. Nauk. SSSR: 1-267. Moskva. Vog e l P., 1974: Kälteresistenz und reversible Hypothermie der Etruskenspitzmaus (Suncus etruscus, Soricidae, Insectivora). Z. Säugetierkunde, 39, 2: 78-88. Wo $1 \mathrm{k}$ E., 1969: Body weight and daily food intake in captive shrews. Acta theriol., 14, 4: 35-47. W o $1 \mathrm{k} \mathrm{K}$., 1976: The winter food of the European water-shrew. Acta theriol., 21, 6: 117-129.

Accepted, June 28, 1977.

\section{A Comparison of Number of Embryos and Measurements of Microtus montebelli in Two Types of Habitats}

Parównanie wymiarów i liczby embrionów u Microtus montebelli żyjących w dwu różnych środowiskach

\section{Yukibumi KANEKO}

Kaneko, Y., 1978: A comparison of number of embryos and measurements of Microtus montebelli in two types of habitats. Acta theriol., 23, 6: 140-143 [With 3 Tables \& 1 Fig.]

External and cranial measurements and number of embryos were compared in the Japanese field vole (Microtus montebelli) between neighboring October populations in different habitats, namely cultivated land and young plantation. It is concluded that habitat differences between the two populations caused the morphological differentiation in males $(H \& B L, B W, C B L, Z W$ and $C-Z)$, while these differences had little effect on female measurements but brought about variation in the average number of embryos recorded.

[Biol. Inst., Fac. Educ., Kagawa Univ., Takamatsu 760, Japan.]

The Japanese field vole, Microtus montebelli (M ilne-Edwards, 1872), is found on Honshu, Kyushu and Sado Islands, and inhabits mainly cultivated land and young plantation. So far as we know, nothing has been reported on the variation of this vole in relation to difierences in habitat. The present paper makes a comparison of external and cranial measurements and number of embryos between neighboring October populations in two habitats in the northeastern part of Hiroshima Prefecture, Honshu. 